\title{
Race and Public Deliberation
}

\author{
TALI MENDELBERG and JOHN OLESKE
}

\begin{abstract}
Although deliberation has a central place in democratic theory, scholars know little about how it actually works. Most deliberative theorists emphasize the many good consequences of deliberation. By contrast, Mansbridge suggests that deliberation in certain circumstances may exacerbate conflict. Scholarship on racial politics suggests that each hypothesis is complicated by implicitly racial language. Using a quasiexperiment, we contrast the rhetoric in two town meetings about school desegregation: a segregated meeting with homogeneous interests, in which segregated Whites unanimously argued against desegregation, and an integrated meeting with heterogeneous interests, in which segregated Whites argued against integrated Whites, Hispanics, and African Americans. We find that (a) deliberation at the segregated meeting maintained consensus among segregated Whites; $(b)$ these citizens used coded rhetoric that appeared universal, well-reasoned, and focused on the common good, but in fact advanced their group interest; (c) deliberation at the integrated meeting maintained the conflict between segregated Whites and others; and (d) there, rhetoric that seemed universal to segregated Whites was decoded by the integrated audience as racist and group interested. We highlight the problem posed by the contested meaning of language and suggest ways to make deliberation more effective.
\end{abstract}

Keywords deliberation, implicit meaning, public discussion, school desegregation, race, racism

Deliberation has been lauded as a central virtue of democracy by thinkers as diverse as Mill, Madison, the anti-federalists, and Calhoun (Fishkin, 1991). Many contemporary theorists closely link deliberation with healthy democracy. Yet, scholars know little about how deliberation in fact works. In this article, we focus on public meetings about school desegregation. Our aim is to understand how citizens publicly and collectively discuss a salient issue when the outcome directly affects their lives. We hope to find out how deliberative democracy operates on the ground, when citizens use it to resolve an issue that counts.

Our analysis rests on a pair of contrasting town meetings in New Jersey, each attended by several hundred people. One meeting, in the town of Leonia, was composed entirely of White participants who opposed desegregation (the "segregated" meeting). The other meeting, in the town of Englewood, was attended by a racially diverse set of participants who had conflicting preferences on integration (the "integrated" meeting). The context of deliberation thus varies from common to conflicting interests and from an all-White

Tali Mendelberg is Assistant Professor of Politics at Princeton University. John Oleske is a law student at New York University.

Address correspondence to Tali Mendelberg, Department of Politics, Princeton University, Princeton, NJ 08544-1012, USA. E-mail: talim@ princeton.edu 
audience to a racially integrated one. We derive expectations about these meetings from deliberative theory and from research on racial politics, examine them against the rhetoric at the meetings, and draw implications for deliberation.

\section{Models of Deliberative Democracy}

\section{Defining Deliberation}

Deliberation is "reflective, open to a wide range of evidence, respectful of different views. It is a rational process of weighing the available data, considering alternative possibilities, arguing about relevance and worthiness, and then choosing the best policy or person" (Walzer, 1997, pp. 1-2). From a wide range of theories, we have distilled the following formal requirements for deliberation: ${ }^{1}$ (a) Meetings are public; (b) citizens reflect and decide collectively rather than individually; (c) citizens have an equal opportunity to participate; (d) decisions turn on arguments, not on coercive power; (e) citizens are fully informed; (f) all alternatives are considered; (g) deliberation is an ongoing process supported by other institutions; and (h) arguments are based on general principles and appeal to the common good, not exclusively to self-interest. ${ }^{2}$

The first four requirements can be thought of as basic procedural rules of deliberation that a deliberative effort should go a long way toward meeting. The two meetings we studied come close to conforming to the basic procedural rules of deliberation: They were public, the discussion was collective rather than individual, each person had a relatively equal opportunity to participate, and the decision, while in the hands of the state rather than of the participants, did not turn on coercive power. The other requirements are better thought of as substantive characteristics of ideal deliberation. No actual deliberation is likely to embody fully these ideal substantive characteristics, but the ideal can serve as the end point of a continuum of good deliberation and as a standard against which actual deliberation can be evaluated. Actual deliberation that essentially conforms to the four basic procedural rules can thus approximate the substantive ideal characteristics to a greater or lesser degree. Some of the ideal substantive requirements are more difficult to approximate than others, of course. The fifth and sixth requirements are probably the most idealistic, since they run against two pillars of public opinion research: First, most citizens are often poorly informed even on salient issues, and second, rarely are all alternatives duly considered (Zaller, 1992). The seventh requirement is easier to approximate, and although the meetings we studied did not meet it fully, they were heavily attended, flanked by other forms of public expression, and supported by other political institutions (having been mandated by the state department of education and led by local elected officials). The eighth (and final) requirement about general principles and the degree to which each meeting approximated it are the main subject of this article. ${ }^{3}$

Do meetings that approximate the basic procedural rules of deliberation also approximate the ideal substantive, rhetorical characteristics of deliberation? We find in writings on deliberation two opposing scenarios, a positive scenario derived from deliberative theorists and a negative scenario derived primarily from the work of Mansbridge.

\section{The Positive Scenario for Deliberation}

Of greatest interest to us is that deliberative theorists particularly recommend deliberation to resolve conflict between opposite interests. Habermas (1989) argues that when 
people's understandings of the norms of communication conflict, they should engage in practical discourse, a formal, reflective discussion of those norms. For Barber, the selling point of deliberation is to take disparate individuals who desire selfish goods and transform them into a community characterized by "public interests, common goods, and active citizens" (1984, p. 179). John Stuart Mill considered deliberation to be the chief virtue of democracy because it allowed-even forced-the meeting of opposing considerations (1859/1975). According to Bickford (1996), Aristotle favored deliberation not only for closely knit polities but also for polities characterized by deep conflict, where deliberation not only ensures sounder public decisions but also enhances people's commitment to resolving conflict peacefully. Warren (1996) argues that citizens should expend scarce resources on deliberation primarily on conflictual issues, since these are the issues that citizens care most about. Even when it fails to achieve agreement, deliberation is expected to broaden people's perspectives by forcing them to take into account an abhorrent point of view, if only to figure out how to persuade their opponents (Gutmann \& Thompson, 1996).

Theorists who seek to expand democracy (expansive democrats, in Warren's term [1992]) and liberal theorists have somewhat different expectations of deliberation, and in particular of its role in resolving conflict. The former mostly expect deliberation to create better democratic citizens and less fractious communities. The latter expect deliberation to create more rational decision making; more tolerant, open-minded citizens; and thus more legitimate, sound, and fair decisions. Both argue that deliberation enhances the quality of such democratic procedures as majority rule and agree that it increases trust in democracy. In sum, across the two variants of deliberative theory, the range of possible desirable effects is as follows: (a) resolve conflict and enhance consensus, (b) make citizens more active, (c) yield decisions more focused on the common good, (d) force citizens to understand opposing perspectives if only to argue against them, (e) yield decisions more grounded in facts and reason, (f) strengthen citizens' commitment to resolving conflict peacefully, and $(\mathrm{g})$ enhance trust in democratic procedures.

What rhetorical effects might our two town meetings produce? We can think of five possible outcomes: (a) The segregated White meeting will heighten consensus among segregated Whites; (b) the integrated meeting will lessen conflict between the opposing sides; (c) segregated Whites will use less self-interested language, make more references to the common good, and show signs of greater tolerance at the integrated meeting, where they are forced to confront others' interests, than at the segregated meeting, where they are not; (d) the racially diverse participants at the integrated meeting will rely at least minimally on arguments about the common good, the opposing sides having fruitfully exchanged views; and (e) each meeting's rhetoric will include reliance on facts and reason. ${ }^{4}$

\section{The Negative Scenario for Deliberation}

Other theorists, however, have expressed skepticism about deliberation, particularly on the ground that it is ill suited to resolve conflict. Warren (1992), who argues for expansive democracy, nevertheless cautions that in the case of conflict over racial inequality (and other arenas of "exclusive group identity goods"), deliberation by itself is likely to "heighten conflict by exposing injustices" and will not create better citizens (p. 21). Merelman, Streich, and Martin (1998) found that the National Conversation on American Pluralism and Identity largely failed to enhance participants' consensual American identity. And our reading of Mansbridge's Beyond Adversary Democracy (1983), to 
date the chief empirical study of formal deliberation among citizens, suggests that collecting a diversity of interests under one deliberative roof is unlikely to produce the civic-mindedness that many deliberative theorists envision or the truth about the common good for which they hope. ${ }^{5}$

Mansbridge offers a spectrum of democracy that runs between two archetypes: unitary and adversary democracy. Unitary democracy is characterized by common interests, equal respect, consensus, and face-to-face contact. Adversary democracy is characterized by conflicting interests, equal protection of interests, majority rule, and secret ballot (1983, p. 5). The meetings we considered do not neatly fit either of these two archetypes (indeed, Mansbridge argues that no actual polity will do so). But because it was largely attended by people who were White, lived in segregated communities, and opposed any measure to achieve integration, the segregated meeting is characterized primarily by common interests - a central dimension of the unitary model. By contrast, the integrated meeting, because it was attended by two kinds of people-racial minorities and Whites who lived in an integrated community and favored concrete measures to encourage racial integration and Whites who lived segregated lives-is primarily characterized by conflicting interests, a central dimension of the adversarial model.

The work of Mansbridge suggests that the segregated meeting, because of its dominating common interests, should engender a rhetoric of consensus and equal respect. By the same token, the integrated meeting, because of its dominating conflicting interests, may engender a rhetoric of discord and alienation, or, to invert the characteristics of unitary democracy, it may create the feeling that equal respect had been violated, and it will lack consensus.

Neither deliberative theorists nor the skeptics say much about how conflict might shape the meaning of the language used in deliberation. Habermas (1989) emphasizes the communicative aspect of deliberation and the need to create shared linguistic meaning, but he does not specify how meaning might be contested in reality. We believe that the language people use-each side's different choice of words and the different meaning attached to these words-is a key to understanding public deliberation. The extent to which the sides share an understanding of basic deliberative norms-what is a universal reason, who belongs to the community whose common good is desired, and what facts are relevant-determines the extent to which deliberation aids in the negotiation of interests.

\section{Racial Rhetoric and Contested Meaning}

To understand the contested meaning of language at our town meetings, we draw on two important aspects of racial rhetoric. First, race is likely to remain an implicit subtext in a discussion among opponents of desegregation, but to be an explicit theme in a discussion between opponents and proponents. Second, a person's race and racial context influence opposition to desegregation and the way arguments for this opposition are interpreted.

\section{Race as an Implicit Subtext}

To be credible in today's racial climate, speakers who oppose integration are highly likely to seek to avoid the perception that they are racist (Schuman, Steeh, Bobo, \& Krysan, 1997). Accordingly, these speakers are likely to rely on nonracial language to express their opposition. Himelstein (1983), for example, found that Mississippi Whites 
who opposed a referendum to improve Blacks' political representation made use of code words that on their face had nothing to do with race, but that echoed the explicitly racial defense of segregation from the 1950s. People who want to argue against integration in a public forum are likely to feel a strong need to ground their opposition in universal reasons and to use nonracial language.

Citizens who wish to argue against desegregation without violating the norm of non-racist speech do not have to invent rhetorical strategies on their own. In part through the deliberate actions of political entrepreneurs, and partly through associations established in the news media, people can speak about racially tinged issues without referring to race and still convey racial meaning implicitly (Entman, 1992; Gilens, 1999; Jamieson, 1992; Kinder \& Sanders, 1996). Richard Nixon, for example, intentionally used the nonracial phrase "law and order" in part to remind Whites of their fear and resentment toward the racial disorders in central cities (O'Reilly, 1995). White citizens tend to respond in a racially charged way to racially tinged issues even when no explicit mention is made of race. When White citizens consider such matters as criminal justice or welfare, they tend to draw on their racial predispositions quite strongly, often more strongly than they draw on principles and ideologies that are racially neutral (Entman, 1992; Gilens, 1999; Hurwitz \& Peffley, 1997; Kinder \& Sanders, 1996; Sears \& Citrin, 1985). White citizens may not always be aware of the racial meaning of their words or of the links that influence their opinion (Mendelberg, 1999). Thus, when White citizens argue against racial desegregation, they are likely to make racially neutral arguments that call on universalist principles, to be motivated in part by racial predispositions, and not to recognize their arguments as racial.

\section{The Impact of Race and Racial Integration on the Discussion of Integration}

The composition of the audience is likely to make a crucial difference both to the kind of rhetoric speakers employ and to the response. Two aspects of composition are likely to be important: whether a significant proportion of the audience belongs to racial and ethnic minority groups and whether participants lead segregated lives. ${ }^{6}$

African Americans and White Americans typically differ dramatically in their views about racial matters (Kinder \& Sanders, 1996; Sigelman \& Welch, 1991). While Whites in many contexts are likely to oppose desegregation, African Americans are likely to support it. Race is highly salient for African Americans, and the African American press and African American leaders are likely to scrutinize political communication for racism and to challenge political messages as racist (Dawson, 1994; Mendelberg, 1999; Sigelman \& Welch, 1991). Moreover, African American citizens are likely to interpret a politician's exhortation to help themselves as positive when it comes from an African American politician but not when it comes from a White politician (Kuklinski \& Hurley, 1994). African Americans are thus likely to express support for desegregation, to decode implicitly racial arguments as racial, and to challenge these arguments as racist. ${ }^{7}$

Whites who lead racially integrated lives have more liberal racial views than Whites whose lives are uniformly segregated. Interracial contact does not always weaken racial stereotypes, but Whites living racially integrated lives are less likely to vote for candidates in the mold of David Duke (Voss, 1996), more likely to vote for Black candidates in the mold of David Dinkins (Carsey, 1995), less likely to rely on racial stereotypes in evaluating racial policies (Kinder \& Mendelberg, 1995), and far less likely to engage in racial harassment or assault (Green, Strolovitch, \& Wong, 1998). We expect, then, that 
Whites who lead integrated lives will perceive more shared interests with minorities than do segregated Whites and that implicitly racial arguments will not seem universalist and well reasoned to them.

In sum, race and language jointly complicate the expectations we derived from deliberative theories and from the work of Mansbridge. A White group resisting desegregation will probably be motivated to use nonracial language, and will sound rational and universalist to itself; it will not sound that way, however, to Whites who lead integrated lives or to racial minorities. A segregated meeting is likely to end in consensus and a sense of shared community in part through its reliance on implicitly racial rhetoric. An integrated meeting is likely to begin and end in conflict, not only about the issue of integration but about the meaning of the language used by segregated Whites.

\section{Background of the Case}

Despite New Jersey Supreme Court rulings empowering the state to combine school districts to ensure racial balance, New Jersey's schools continue to be the fourth most segregated in the United States. The town of Englewood, population 24,850, is $45 \%$ White, 36\% African American, and 14\% Hispanic (New Jersey State Data Center [NJSDC], 1994, p. 23). At the time of the meetings, its high school was $92 \%$ African American and Hispanic. In contrast, the surrounding towns of Englewood Cliffs, Leonia, and Tenafly have large White majorities (and a growing middle-class Asian population), both in population and in school enrollment (Board of Education v. Board of Education, 1992). ${ }^{8}$

The desegregation controversy in Bergen County began in 1965, when the town of Englewood Cliffs, too small to have its own high school, signed a contract to send its students to Dwight Morrow High School in Englewood. In 1977, Englewood Cliffs petitioned the state commissioner of education to allow it to end its contract with Englewood and choose a new district for its students. By that time, Dwight Morrow had become a majority African American and Hispanic school. The petition was denied, but in 1982, Englewood Cliffs and Tenafly entered into a new, informal sending-receiving relationship anyway, later ruled to be in violation of state law. Tenafly sent solicitations to White parents in Englewood and Englewood Cliffs, offering to take on tuition-paying students, and Englewood Cliffs assisted parents in switching from Englewood (Board of Education v. Board of Education, 1992). Over the course of the next eight years, the commissioner and state board of education repeatedly ruled that Englewood Cliffs students could obtain a good education at Dwight Morrow High School in Englewood and denied Englewood Cliffs' petition to sever its relationship with Englewood. An administrative law judge agreed with the commissioner that Englewood's was "a very good school" and prohibited Englewood Cliffs from severing its relationship with Englewood, since this would harm Englewood's Black and Hispanic children (Board of Education v. Board of Education, 1992). In 1993, the state supreme court upheld a lower court ruling that enjoined future sending-receiving relationships between Englewood Cliffs and any district other than Englewood and ordered the state's department of education to study ways to integrate Englewood with the surrounding districts (Board of Education v. Board of Education, 1993).

The department proposed a variety of plans to "regionalize," that is, create an integrated regional district. The plans varied in their geographical extensiveness, in whether or not they involved busing, and in whether Englewood would send or receive children. With this wide latitude for compromise, the department held five town meetings in September and October of 1995 to discuss which plan should be implemented. 


\section{Method and Participants}

Our analysis is based on the department's videotape of the first and last town meetings, ${ }^{9}$ providing eight hours of complete and unedited coverage, and on local newspapers and our informal observation of the county. Participants were told that the meetings were an opportunity to express their opinions on how regionalization should proceed. Speakers were given five minutes to speak and were chosen on a first-come, first-served basis. We rely on quantitative classification, interpretive analysis, and illustrative quotes (Delli Carpini \& Williams, 1994, p. 71). ${ }^{10}$

The demographic breakdown of speakers and audience at the two meetings is provided in Figure 1, and the percentages of pro-regionalization and anti-regionalization phrases and speakers are provided in Figure 2. It is clear from these figures that the Leonia meeting was predominantly White and included almost no Englewood residents, while the Englewood meeting was racially diverse and represented diverse preferences. Approximately 1,400 people attended the Leonia meeting, $10 \%$ of Leonia's population (although residents of other towns attended as well). Forty-two people spoke, and, as Figure 1 shows, all of them were White. As the skewed distribution in Figure 2 shows, only one of the speakers was in favor of regionalization, and that speaker was a resident of Englewood; all of the other speakers were from Leonia or Tenafly. The audience included fewer than 10 African Americans.

Estimates of attendance at the Englewood meeting range from 1,200-1,800 people, mostly, but not exclusively, from Englewood (about 6\% of Englewood's population). As Figure 1 shows, the audience and speakers at the Englewood meeting were much less racially homogeneous than at the Leonia meeting. Of 44 speakers, 25 were White, 15 were Black, and 4 were Hispanic. Thirteen speakers, all White, were from Leonia, Englewood Cliffs, or Tenafly. As Figure 2 shows, those 13 spoke against regionalization; the rest, all from Englewood, spoke in favor of it. ${ }^{11}$

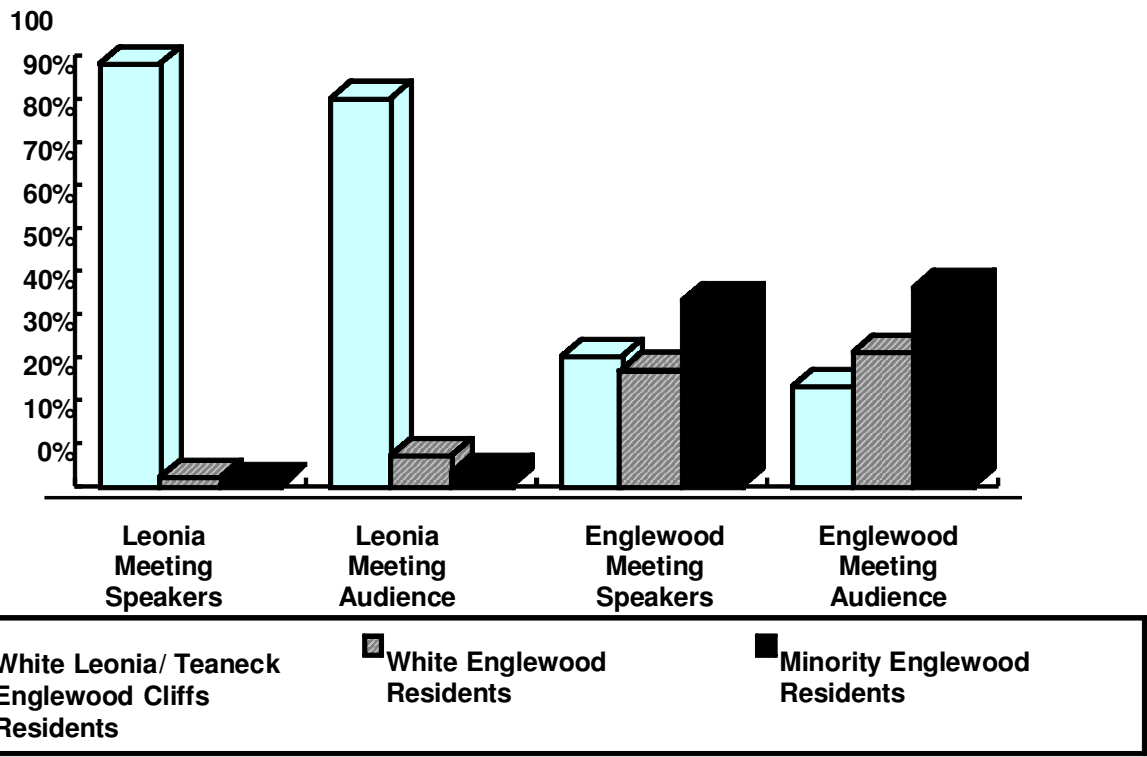

Figure 1. Demographic characteristics of audience and speakers. Percentages for audiences are approximate and are based on frames of each meeting's videotape, which show full views of the audience. 

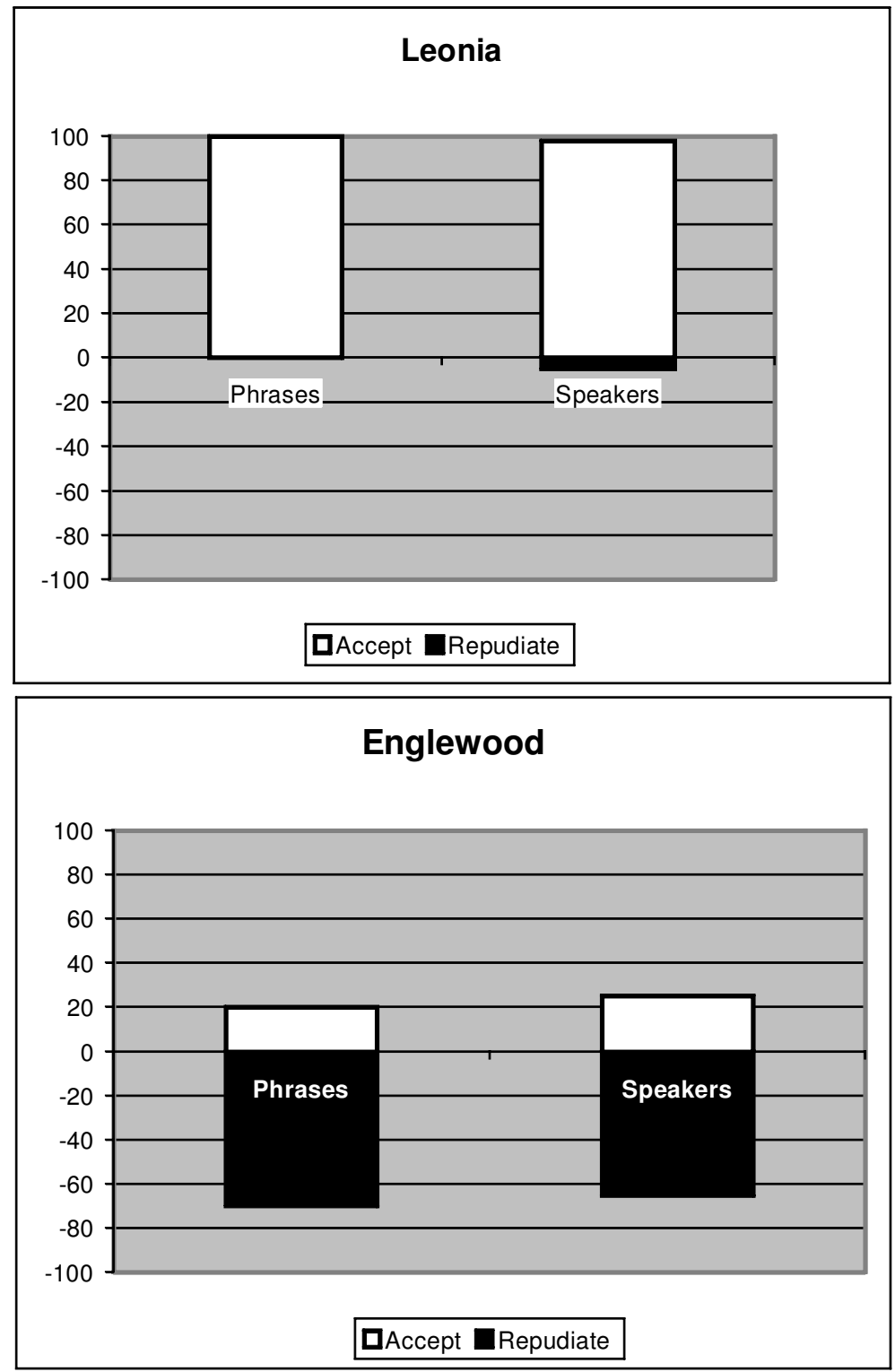

Figure 2. Speakers and phrases accepting or repudiating anti-regionalization arguments, separately for each meeting. Speakers: (Number of speakers on a given side)/(Total number of speakers in a given meeting). Phrases: (Number of times a phrase on a given side is mentioned)/(Total number of phrases in a given meeting).

\section{Segregated White Meeting: Leonia}

\section{“Neighborhood Schools"}

The phrase "neighborhood schools" was the most often used of any of the anti-regionalization arguments and the second most popular phrase judging by the percentage of anti-regionalization speakers (see Figures 3 and 4). It tended to elicit cheers from the 

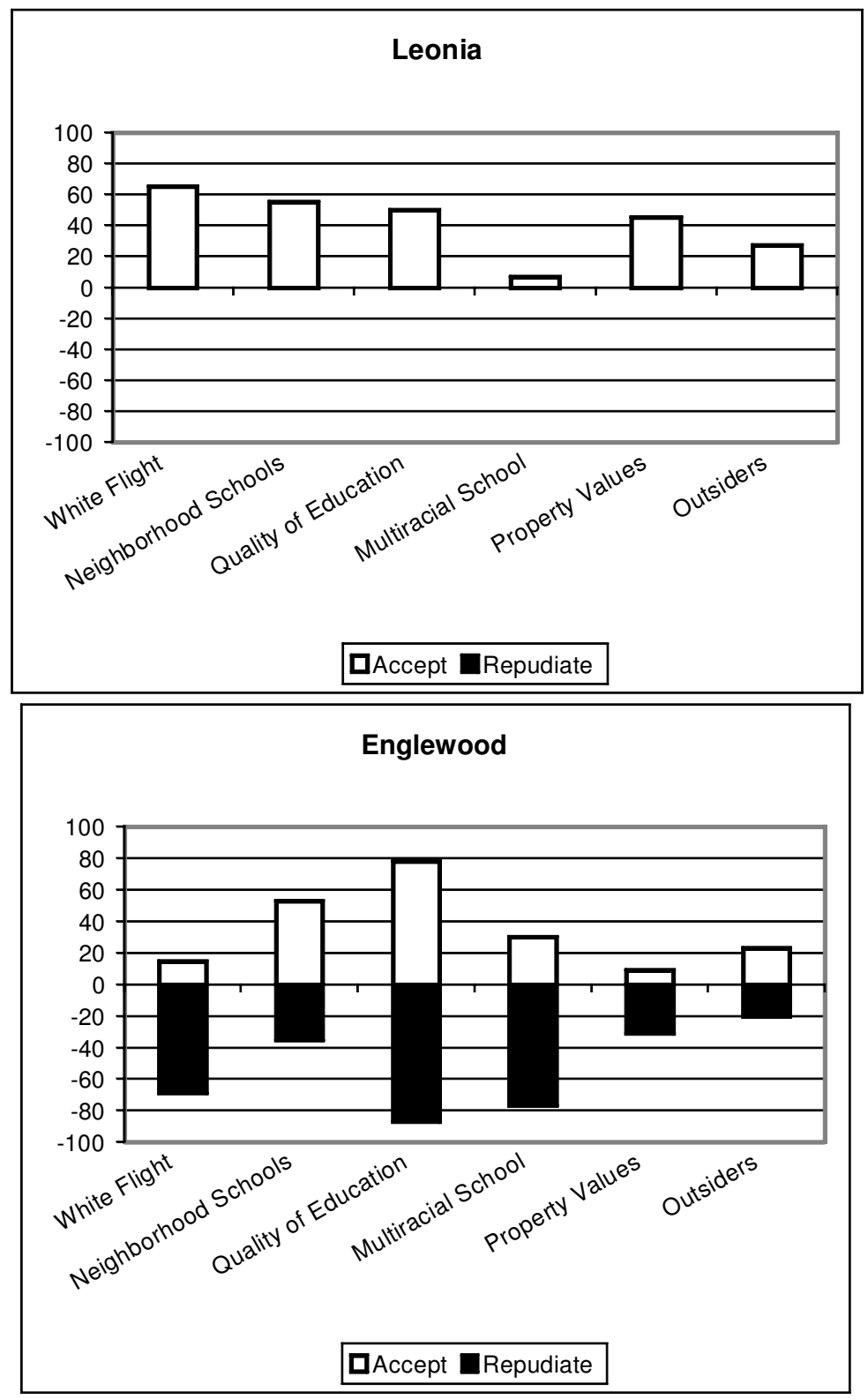

Figure 3. Speakers accepting or repudiating anti-regionalization arguments, separately for each meeting. [Number of speakers of each phrase)/(Total number of speakers on a given side).]

audience, befitting its adoption by the anti-regionalization movement as its slogan. ${ }^{12}$ Four of the speakers who used the phrase elaborated on what it meant-a school located in the town whose children it served and one in which parents could "feel at home." One speaker said, "I strongly suggest keeping elementary school children at home where they can best receive support from nurturing parents and the local community." But most speakers used the phrase with no explanation. For example, the first speaker, a 

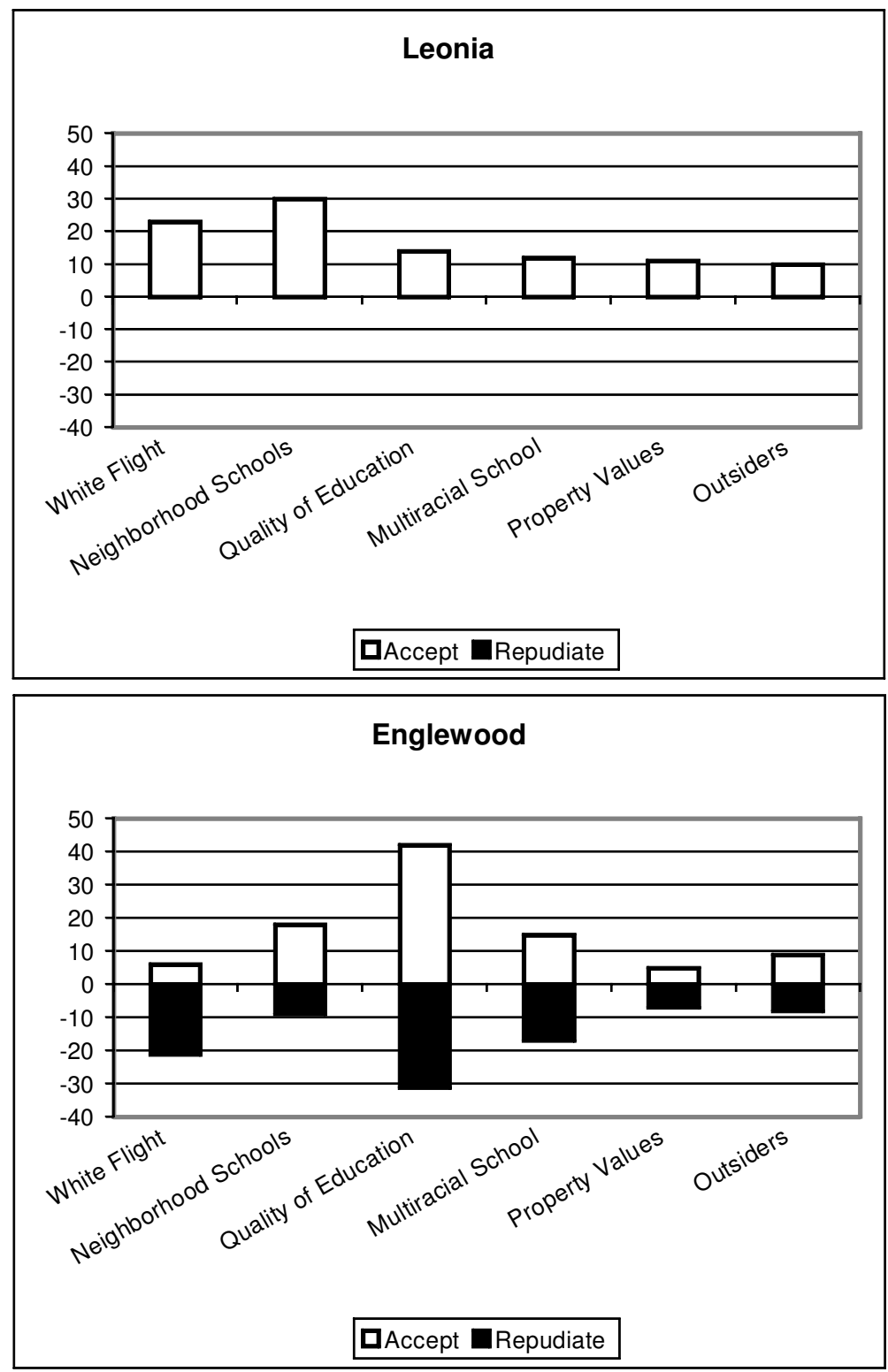

Figure 4. Phrases accepting or repudiating anti-regionalization arguments, separately for each meeting. (Number of mentions of each phrase)/(Number of mentions of all phrases on a given side).

state assemblyman representing Leonia, declared that he would do "everything in my power to keep the state from destroying neighborhood schools."

While not a racial slogan in itself, and while on the surface a legitimate and universalist argument, "neighborhood schools" plausibly carried a good deal of racial meaning and did not consider important and relevant facts. First, most of the plans under consideration by the state would not involve a significant movement of children from Leonia to other schools. Rather, most plans would allow students from Englewood schools to attend school in neighboring districts. The primary way that "neighborhood schools" in 
Leonia might be undermined by regionalization is by the arrival of African American and Hispanic students from Englewood. Second, parents ordinarily do not mention neighborhood schools among things they want in education (Hochschild, 1984; Schneider, Marschall, Teske, \& Roch, 1998). The argument for neighborhood schools was thus at least in part an argument against bringing minority children to White schools.

\section{"White Flight"}

Twenty-seven speakers claimed that "White flight" would keep any regionalization plan from working. Although the use of this phrase did not draw the thunderous applause of "neighborhood schools," it was an element in more speeches delivered at the meeting than any other phrase (see Figure 3), making it the second most popular of the phrases against regionalization (see Figure 4). Speakers claimed that regionalization would lead White parents to withdraw their children from the public schools or to move out of the district altogether. Consequently, successful schools and the communities outside of Englewood would erode.

Expressing a supposed understanding of what racial tensions can do would seem to meet the requirement of deliberation. But while acknowledging that racism exists, speakers continued to deny that anyone present opposed desegregation for racial reasons. The "White flight" argument was thus not an acknowledgment of Englewood's claims that Leonia had discriminated based on race and might continue to do so. It was a way to demonstrate that speakers were not themselves racist while at the same time threatening consequences that could not arise without racism. This technique placed the existing racism at one remove, serving to make the opposition at the meeting more legitimate.

\section{"Property Values and Taxes"}

The claim that "property values will fall and taxes will rise if school regionalization is forced upon Leonia" was advanced by 18 of the speakers. The reasoning for this claim, when reasoning was supplied, is that property in Leonia would be in lower demand if Leonia did not have its own school system, and the town would be forced to raise taxes.

This argument rests on shaky factual and logical ground. First, property values in northern New Jersey's other two regionalized districts rose after regionalization, a point made in court cases and local newspapers. Second, the courts found that there is little or no evidence to indicate that regional districts are less effective than small local ones. In fact, regional districts may be more efficient and thus may save money.

Only 2 of the 18 speakers who used this argument elaborated on their reasoning. This brevity creates ambiguity about why property values would fall. A drop in property values is far more often associated with minorities moving into an area than with the regionalization of a school district. One White parent told The New York Times before the meeting, "I'm not a bit prejudiced; but Blacks moving in will hurt property values" (Stewart, 1995). The ambiguity of the phrase during the meeting allows the audience to think that integrating the schools would encourage African Americans and Hispanics to move in. The financial arguments built on fears that were not well supported by relevant facts.

\section{“Quality of Education”}

Twenty-one of the speakers made statements such as "I will not allow the quality of my child's education to be sacrificed to solve someone else's problem." Speakers defended 
this position with facts more often than they did any other argument, relying on the statistic, printed in the area's leading newspaper, that SAT scores at Englewood's Dwight Morrow High School were more than 300 points lower than at Leonia High School. Speakers concluded that in a regional district that included Englewood, all other districts would be dragged down. It is unclear whether speakers were worried about Englewood's high school or Englewood's students.

The SAT statistic at first seems appropriate to use for an argument against the quality of Englewood's school, but a closer look suggests otherwise. Englewood is the only municipality in the area with substantial rental housing and a low income population (NJSDC, 1994, p. 23). As a result, Englewood students often bring educational problems with them to school. In addition, because of Englewood's rental housing market, nearly $40 \%$ of Dwight Morrow's 1995 graduates did not start high school there. Their scores do not fairly represent Dwight Morrow's capabilities.

A truer test of the ability of the Englewood high school to provide a quality education to students who can and want to take advantage of it for four years is college admissions. Dwight Morrow has a strong college preparation program, and graduates who go on to college attend schools as good or better than graduates from surrounding districts. A Yale admissions officer testified in court that Yale recruits and admits Dwight Morrow students every year. Dwight Morrow sends a large number of students to other Ivy League colleges as well. In addition, the courts repeatedly ruled that while Dwight Morrow's quality had declined during the late 1970s and early 1980s, since then its administrators had corrected the problems and the school was "very good." Dwight Morrow offered a wider range of courses than the surrounding schools; its levels of drug use, violence, and absenteeism were no higher than the other schools' (and drug abuse may have been less common); and it offered racial diversity that the courts-and elite colleges_considered a significant educational advantage. Still, participants at the Leonia meeting continued to believe that Dwight Morrow was "broken beyond repair."

Perhaps Leonians' worry about quality of education was less about Englewood's high school than Englewood's children. But, if so, their worry focused on only some of Englewood's children, those they had not solicited, who tended to be African American and Hispanic. It is likely that Leonians sought to avoid poor students, whom they believed were predominantly Black and Hispanic, rather than Black students regardless of class. But the outcome was to draw a line between two groups: Black and Hispanic children versus others.

In a study of suburban New Jersey, Schneider et al. (1998) found that when given a choice among schools, White and middle class parents do not base their decision primarily on schools' SAT performance. In fact, these parents place less importance on a school's test scores than do Black and lower-class parents (Schneider et al., 1998). Leonians' emphasis on test scores in the regionalization controversy thus seems more of a legitimizing argument than a consistently held preference.

\section{“Outsiders"}

Eleven speakers expressed the view that "outsiders" had no business telling Leonians what to do with their school system. The president of the Leonia Board of Education delivered a vigorous criticism of the Department of Education in which he repeatedly used the phrase (six times in 5 minutes). "Outsiders cannot and must not be allowed to dictate to us what is right and what is wrong for our children," he said, as the audience gave him a standing ovation. 
Except during the president's speech, however, the "outsiders" in question were never clearly identified. Some speakers implied that the state was their target, but others did not. This vagueness, similar to the ambiguity of "neighborhood schools," left the meaning of "outsiders" to the interpretation of the audience. "Outsiders" might refer to the state, but it might also refer to the majority-minority residents of Englewood who had brought integration to the agenda or to anyone outside Leonia who did not share Leonia's demographic makeup. "Outsiders" did not mean White students from outside Leonia; after all, these students were actively recruited by the school system. While the argument against outsiders may be a legitimate claim for local autonomy, it is also in part a nondeliberative argument for racial segregation.

\section{“Multicultural"}

The 13 speakers who mentioned multiculturalism claimed that Leonia's is already an integrated school district. Three speakers offered the statistic that Leonia schools are $40 \%$ non-White. One speaker proudly described the world map and national flags on display at Leonia Middle School as evidence that the school system already strives for ethnic diversity. "I chose to live in a town that has a school system that is over 53\% non-White. In Englewood Cliffs we have Chinese, Japanese, Cubans, Africans, Romanians, Indians," said one speaker.

The "multicultural" phrase appears to be a deliberative concession to the other side's point of view. But it is perhaps the most obviously misleading of the arguments we have considered. Leonia High School is patently segregated, not $40 \%$ non-White. The $40 \%$ figure includes "international students" from such countries as Czechoslovakia, Romania, France, Denmark, and Italy. In fact, only 25\% of Leonia's schoolchildren are non-White, and most of them are Asian American (whose families are well integrated in the towns around Englewood). Of Leonia's high school students, only 6\% are Hispanic and $1 \%$ are African American. The "multicultural" argument selectively ignores information that is publicly available and obvious to anyone who strolls down the hallways of Leonia's schools. Its misleading but believable logic allows White individuals to stand against racial integration while appearing to be antiracist and to take into account the other side's point of view.

\section{Segregated Meeting: Summary}

On the surface, these arguments appear to be plausible candidates for good deliberation. The arguments seemed universal, that is, to rest on principles with which an openminded person could agree, such as local control over education or ensuring that individuals who did not themselves discriminate against minorities are not forced to bear the cost of integration. The arguments often appeared oriented to the common good, advancing collective goals such as a quality education for the community's children, avoiding the emigration of community residents, and maintaining the community's well-functioning neighborhood schools. While some speakers worried about their own children, this was not the dominant mode of argument. Speakers did not include Englewood in their conception of community, a point to which we return later, but they spoke of their community, not just of themselves. Speakers repeatedly attempted to "deracialize" their arguments by disclaiming racism, thus appearing to meet the deliberative criterion of tolerance. (In fact, the word segregation was never mentioned by anyone speaking 
against integration.) Finally, facts and reasoning were heavily used, further lending the discussion the appearance of a good deliberation.

However, a closer examination casts doubt on the extent to which these arguments approximate good deliberation. Speakers ignored commonly known facts and exaggerated or manufactured other "facts." Taken individually and out of context, the arguments often do not seem to be about race, much less racist. But placed in context, the arguments suggest that African American and Hispanic people would threaten the community, the quality of life, and the life chances of Leonia's residents. The arguments at the meeting thus largely do not conform to the hopes of deliberative democrats and conform fairly well to the expectations we derived from the work of Mansbridge and the literature on racial communication.

Only one speaker, a White mother of a child in the Englewood school system, raised the possibility that the resistance to integration was racially charged. She identified the arguments and their underlying meaning as "racism, pure and simple." She was heckled throughout her speech. But one month later, at a meeting dominated by integrated Englewood residents, many speakers made her point to the sound of applause.

\section{Integrated Meeting: Englewood}

Encapsulating the course the meeting was to take, the White president of the Englewood Board of Education opened the meeting by saying: "Our students can and do get a quality education at Dwight Morrow High School. This talk about SAT scores and quality education is just a smoke screen for the hidden agendas of politicians and racists." The audience broke into applause and did not quiet for several minutes. The members of the Englewood board-four African Americans, four Whites, and one Hispaniceach spoke in support of regionalization. The focus of their arguments was the charge that the opposition was racist. They described several incidents of racial harassment, including a letter to board members, postmarked in Leonia, that said "race traitors will pay with their blood."

Subsequent speakers also interpreted the arguments of Leonians as misinformationshrouded, coded racial language. The claim that Leonia schools were "multicultural" drew criticism; "White flight," "property values," and particularly "quality of education" provoked anger.

\section{The Englewood Debate, Part 1}

The 13 speakers from outside Englewood, all opposed to regionalization, relied primarily on arguments made at the Leonia meeting but also introduced new ones. The most popular new idea was that Englewood alone was to blame for its problems, so Englewood should solve its problems on its own. "Englewood's politicians must stop blaming everyone else for its problems," said one White speaker from Tenafly. Another charged that "the leadership of Englewood ... [ [made] liberal use of racial demagoguery to bludgeon into submission all opposition." Six of these speakers insisted that "forced" regionalization would "destroy successful programs" to "fix somebody else's problem." The other new argument, advanced by two speakers, was that government attempts at integrating schools were ineffective. One speaker quoted from an opinion by Justice Clarence Thomas arguing that desegregation did not benefit minority students. Another speaker charged that "the state has spent enormous amounts of time, money, and effort on a study to determine how to regionalize without even determining whether regionalization works." 
More popular than the new arguments were two familiar arguments. One of these, "quality of education," became an almost universal theme among speakers from outside of Englewood. Along with "multicultural schools," it was the only phrase to be used more frequently and by more anti-regionalization speakers at Englewood than it had been at Leonia, as Figures 3 and 4 show. A more aggressive, accusatory version of the old argument was used by several speakers. One said that "Dwight Morrow is a complete failure to the community of Englewood, and its unelected Board of Education is probably at the root of the school's problems." Another declared that he wanted the very best for his daughter's education and claimed that "any situation forcing regionalization with Dwight Morrow" would "destroy her chance to excel."

\section{The Englewood Debate, Part 2}

The two new arguments were met with vigorous opposition from Englewood residents. They argued that segregation was not Englewood's responsibility alone; the other school districts had broken contracts and illegally solicited Englewood's White students, increasing the level of segregation at Dwight Morrow. In addition, several Englewood residents argued that segregating the schools was illegal according to the U.S. Supreme Court in the Brown decision. The Tenafly resident who quoted the comment from Justice Thomas could not get past the word "Clarence" before he was heckled. In response to both arguments, Englewood residents said that they felt "patronized" and "ignored" and that "segregation is not even recognized as a bad thing, so evading responsibility for it becomes even easier."

The "quality of education" argument also met with a hostile reception by Englewood residents. First, Englewood residents rebutted the content of the argument. Several Englewood parents spoke about the fine education Dwight Morrow was providing to their children. "My younger son is in a program that won best program of its kind in the state of New Jersey," said one parent; "the third and fourth grade children [in our neighborhood school] just got results from the standardized test they took . . . many of our children scored in the 99th percentile [applause] . . . with third graders working on the eighth grade level." Many speakers spoke proudly of having attended Dwight Morrow and testified to the excellent education they had received there. "I stand here today as a graduate of Dwight Morrow High School [applause] . . . Dwight Morrow has a proud history of excellence that spans over half a century [applause]." One parent elaborated the reasons, including a relatively poor and transient student body, for Dwight Morrow's lower SAT scores and emphasized that these scores do not accurately portray the ability of teachers and administrators. Many speakers argued that a quality education included exposure to children of other races, specifically the mingling of White and African American children. One Englewood parent criticized the "multicultural" argument:

They are not really facing the issue. . . . How many children in these other towns have African American children in their classes? I believe it is important for all Americans to know African Americans with the intent to put an end to the racial tensions in our country. White children must play, eat and have the same teacher as Black children.

Second, the ostensibly nonracial arguments used by the opponents of integration were challenged as racist. One Englewood speaker said that he received a letter that stated, "Yes, Dwight Morrow provides strong college prep programs, but you in Englewood 
have to make the school $50 \%$ White before we are going to send our children there." Some Englewood speakers charged that "quality of education" was a racially coded phrase. "What this sort of language really says," said one parent, "is that our children, Black children, are inherently inferior and that an integrated education which includes them is also inherently inferior."

Englewood residents responded with frustration to what they perceived as an attempt to mask "greed" and "racism" in neutral language and to the White towns' mobilization against regionalization. "I resent the bashing of our kids by our neighbors who are afraid of change," declared Englewood's mayor. In Leonia, Tenafly, and Englewood Cliffs, most residents had tied yellow or orange ribbons around the trees in their yards to symbolize their unity against integration. A drive one of us took through the area revealed that many yards had ribbons on all of their trees. Ten of the Englewood speakers noted the extreme offense this gesture had given them. One woman who had lived under apartheid in South Africa said that the ribbons reminded her "of the signs at the borders between the rich White areas and the poor Black townships." Others compared the ribbons with the burning crosses of the Ku Klux Klan and the "white" and "colored" signs of the Jim Crow South.

Many Englewood residents responded with intense defensiveness and blanket condemnation. "If Englewood offered a physics class taught by Albert Einstein, the students of [the White towns] would not attend, and if we offered a class pertinent to religion taught by Mohammed, Moses, and Jesus, those students wouldn't come here," said one Black woman. A Black member of the Englewood board declared that he would "personally take on anyone" who brings "physical or mental harm to our kids." One speaker detailed the racially selective solicitation by Leonia as evidence of racism, and another White speaker told of blatant discrimination directed by White Tenafly students against his White daughter's Black Englewood teammates. Some speakers used the word racist freely and without specifics, and some indulged in what seemed to be exaggerations. One White parent confessed to unwillingness to let her child attend school in Tenafly or Leonia because her child was afraid of being attacked by the Ku Klux Klan. One Black parent who attended the meeting at Tenafly said he realized at that meeting that "this is purely an issue of race" when he had detected skepticism from the audience there to one speaker's assertion that Dwight Morrow was not populated by "crack dealers and rapists." The meeting reminded him of "Georgia in 1974" when he "had seen a White only bathroom sign with one strip of paint over it . . it should have been taken off the door but it was just like, 'you know, we'll bring this back when we want to.'" The fear of the KKK and the comparison with Jim Crow in Georgia were effective ways of conveying understandably strong feelings about the racial tenor of the White towns' position, but as a description of reality they probably contained some element of exaggeration. As in the Leonia meeting, the heckling also constituted a problem from the perspective of deliberation. The strong response of many Englewood residents was based in part on appropriate facts and considerations, but in part not.

\section{Integrated Meeting: Summary}

The integrated meeting did not seem to lessen conflict and alienation. Segregated Whites did not change their arguments, or acknowledge the arguments of Englewood residents, or behave differently here than they had in Leonia, except perhaps in a more antagonistic direction. They apparently believed in the legitimacy of their own arguments and saw no need to moderate them. Englewood's integrated citizens in turn focused on 
rebutting what they perceived to be the other side's group-interested, exclusive, and racist arguments. Englewood residents repeatedly indicated their skepticism toward the possibility of compromise by calling on the state's executive branch to enforce the court's ruling, even if this meant forcing the surrounding communities to regionalize with Englewood. Several Englewood parents said that the charges of an "inferior" education had been so hurtful to their children that the meetings should not have been held. The final Englewood speaker neatly summed up the Englewood view: The White opposition was simply "a loud mob led by fear and ignorance rather than reason and common sense."

Perhaps the key problem of the Englewood deliberation is that the context of the meeting, the arguments of the non-Englewood Whites, and the Englewood response undermined the possibility of building shared meaning. The racist meaning that Englewood residents gleaned from Leonians' arguments was unlikely to be considered by Leonians as a valid interpretation. Repeatedly, non-Englewood speakers used such phrases as "the real issue here is not race; it is institutional failure." Only one speaker at the Englewood meeting said that she had realized she had been racist, and she was an Englewood parent who had sent her children to Englewood schools. Non-Englewood residents were not likely to reconsider their claim that race had nothing to do with the problem or with their opposition after being accused of racism. In turn, Englewood residents were unlikely to change their conclusion that non-Englewood residents considered African American and Hispanic children "inherently inferior." Any criticism of Englewood's schools or its leaders was interpreted by Englewood residents as a criticism of Englewood's racial minorities. Good deliberation requires that the opposing parties try to acknowledge the validity of the other side's interpretation of language, but this was unlikely in a dispute over the definition of community.

\section{Conclusion}

The rhetoric at these meetings was not the ideal deliberation envisioned by many deliberative theorists. ${ }^{13}$ Some theorists might object that the meetings failed to provide an adequate opportunity to deliberate. We consider this problem subsequently, but for now, we note that the meetings did go a long way toward meeting the most basic procedural rules of deliberation: They were public, they entailed a collective discussion, there was a relatively equal opportunity to participate in all phases, and decisions were driven by arguments rather than power. Thus, the meetings were a rare opportunity for citizens to publicly and formally discuss a crucial matter of public policy. We use the substantive criteria of ideal deliberation to analyze how and why the rhetoric was problematic.

The deliberation we studied was deficient in the following ways: (a) The segregated meeting ended in consensus, which is a desirable outcome for some theorists, but it did so through rhetoric that allowed participants to legitimize their opposition to integration; (b) the integrated meeting did not lessen conflict, because the implicitly racial rhetoric used by segregated Whites was decoded as racial and racist, and the meeting was not conducive to discussing ways of reducing that racism; (c) segregated Whites did not use less group-interested language, or make more references to the good of both communities, or show signs of greater tolerance at the integrated meeting, since in their interpretation their rhetoric already was legitimate; (d) integrated citizens at the integrated meeting did not express mutual understanding, because what they decoded made them too angry and defensive; and (e) facts and reasoning played an important role, but in a highly selective, self-serving way not endorsed by deliberative theorists. 
What was perceived in Leonia as nonracial and well reasoned was perceived in Englewood as racial and poorly reasoned. What allowed speakers to respect each other as civic-minded community members in Leonia became a marker of group interest and opposition to a broader community in Englewood. What counted as universal language for one community counted as the opposite in the other.

In short, the positive effects of deliberation rest on the ability of the opposing sides to communicate about their disagreement. When the meaning of speech is contested, deliberation is unlikely to be reasoned or consensual (see also Warren, 1992, p. 15). ${ }^{14}$

The two expectations we derived from Mansbridge's work each found support here, although each is complicated by racially coded language. First, Leonia's segregated meeting, with its common interests, ended in a sense of equal respect and consensus. However, it did so as a racially segregated community, because it was a racially segregated community. The White citizens at Leonia's segregated meeting engaged in what Mansbridge calls the "enclave model of democratic deliberation" (1996, p. 58). But ironically, Mansbridge recommends this model as a way for subordinate groups to articulate their collective interests in a safe setting, to understand themselves better, forge bonds of solidarity, and hammer out conceptions of self, community, justice, and universality. These meetings allowed the privileged group to do this, and do it effectively. Faced with concerted opposition to regionalization, the state abandoned regionalization and opted for segregated Whites' preferred solution: It proposed that Englewood "work to correct the imbalance itself." Englewood must now create a special magnet school, with technical aid but no funds from the state.

The second expectation we derived from Mansbridge's work-that the adversarial meeting in Englewood would end in alienation-was fulfilled. But this was in part due to the contested meaning of language. Englewood residents seemed angry not only about what they perceived as racism from the other side, but at what they saw as an attempt to hide racism behind a veil of legitimate words. The conflicting interests would have been more easily resolved if the issue had not also included a conflict over basic respect. At issue at these meetings was the affront to human dignity, an affront that one group perceived and the other group denied.

The problems at these meetings are likely to arise outside the realm of race as well. Racism undermines deliberation because it produces strong negative assumptions about the opposing deliberators. The same is probably true of sexism, nationalism, and other sets of ideas that denigrate an out-group.

\section{The Closed Circle of Deliberation}

Some theorists have recently articulated the need to build more bridges between deliberative theory and political reality (e.g., Gutmann \& Thompson, 1996). Our empirical study, although it is a first, tentative step, suggests that meaningful deliberation among citizens is hampered by the difficulty of fully implementing the rules that ideal deliberation requires. Entman and Rojecki put the problem well: "The more social capital, the more trustful communication among diverse members in a society and the better able it is to work out its problems. ... [Yet] the racial divide embodies the single most serious instance in the U.S. of low social capital across groups" (1996, pp. 1-2). Subordinate groups cannot rely on deliberation to secure equality and build a community with dominant groups, because deliberation must have equality and community as preconditions to succeed. The situation is a closed circle: One cannot get what one needs when the process of obtaining it is itself tainted by the lack of what one needs. 
Theorists who tackle inequality at length tend to focus on the twin facts that dominant groups silence speakers from subordinate groups and that subordinate speakers do not feel empowered to speak (Mansbridge, 1983; Sanders, 1997; Young, 1996). However, these analyses leave out the other problem with inequality: the very unwillingness of dominant groups to enlarge their community to include subordinate groups in the first place. Furthermore, the meaning of language was contested, making the deliberation itself an issue. On our reading, the anger and frustration of minority citizens and their integrated White allies was a product not so much of feeling silenced but of accurately perceiving that, in the guise of principled, rational speech, they and their children were being set apart in an isolated community and marked as inferior citizens. The question remains as to how to get dominant groups to listen to subordinate groups. How do subordinate groups get dominant groups to the table at all ${ }^{15}$

\section{How to Break the Closed Circle}

Our suggestions spring from the fact that the fault line at the integrated meeting was not race per se, but the divide between integrated and segregated. One key to deliberation may be to make sure that those who deliberate lead their lives in common. As Young says, "The unity that motivates politics is the facticity of people being thrown together. . . a polity consists of people who live together, who are stuck with one another" (1996, p. 126). Bridging the divide of segregation clearly faces serious problems of its own, as scholars of desegregation repeatedly warn (e.g., Hochschild, 1984). But by contrast to the solutions of several deliberative theorists-equalizing money, strengthening parties, or relying on characteristics of rhetoric-it is a remedy that addresses the problem directly. By tackling the social and institutional context, this solution avoids the closed circle problem in which deliberation cannot bring about equality and community unless they already exist. Many concrete efforts to achieve integration, while problematic, are already in place. The effective among them should be strengthened and accelerated.

Our solution, by implication, cautions against implementing deliberation as a seemingly costless way to begin to address long-standing problems. Bill Clinton's major policy initiative on race, for example, has been the "national conversation" (see also Merelman et al.'s 1998 study of the National Conversation on American Pluralism and Identity). Our analysis advises against pursuing deliberative initiatives before structural change, and certainly against replacing the latter with the former.

Deliberative solutions, however, can also have a place, if they take into account the lessons of the interracial contact hypothesis (Brewer \& Miller, 1988). One of these lessons is that the circumstances of contact must be carefully structured so that the line of demarcation between people becomes less salient to them (e.g., selecting neutral discussion sites). Another lesson is to reduce threats to group interests (e.g., safeguarding educational quality). Two other insights, not drawn from the contact hypothesis, also deserve greater attention. The meetings in Bergen County failed in part because local leaders mobilized citizens against desegregation. If the state first requires negotiation between local officials, on the model of business-labor disputes, and leaders agree to compromise, subsequent public meetings may be more effective (see Elster, 1998, on negotiation). Also, Barber's recommendation that deliberation be an ongoing institution seems crucial, especially if it instills in citizens the perception that their fates are linked and that they must return to the table until they resolve the dispute. In informal, interpersonal discussion, the more frequent are discussions across lines of political 
difference, the more likely people are to know the other side's reasons for its position, and the more tolerant they become (Mutz, 1999). Properly structured, formal deliberation may have the same effect.

Productive deliberation is difficult to achieve because it rests on language. The farther apart the deliberators, the farther apart their interpretation of what counts as universal, community-oriented, and open-minded language. For deliberation to achieve its promise, it requires structured, selective implementation buttressed by institutions that promote interdependence and equality. Our challenge is to specify what those institutions might be.

\section{Notes}

1. The following draws on Barber (1984), Benhabib (1996), Bickford (1996), Bohman (1996), Chambers (1996), Cohen (1989), Fishkin (1991), Gutmann and Thompson (1996), Mansbridge (1983, 1990, 1996), Sunstein (1993), and Warren (1992, 1996).

2. This discussion reflects the difficulty of distinguishing in the work of most theorists between necessary and merely desirable preconditions for deliberation and, more important, between preconditions for deliberation and the beneficial outcomes anticipated from deliberation. Also, although the meetings may have been different had a vote been required, this is not necessary in all theories. In any case, the meetings did have an informal impact on policy, as the conclusion discusses.

3. The eighth requirement has been challenged recently. Some theorists argue for a conception of ideal deliberation in which self-interest informs arguments about the common good rather than being excluded altogether (Mansbridge, 1990; Sanders, 1997). However, this is typically recommended as a way to level the rhetorical playing field for subordinate groups, whose interests tend to be neglected in deliberation about the common good, a point to which we return in the conclusion.

4. Agreement in favor of segregation may be viewed by deliberative theorists as a problem rather than as a desirable outcome. Each meeting may also generate political activity and increase the commitment to peaceful and democratic resolution of the conflict, but we are unable to test these expectations. In addition, frequent discussion may increase individuals' cognitive sophistication (Gastil \& Dillard, 1999; Mutz, 1999).

5. Theiss-Morse, Marcus, and Sullivan (1993) examine solitary reflection rather than public deliberation. The results from the National Issues Forums and the National Issues Convention are just now beginning to be widely circulated (Gastil \& Dillard, 1999).

6. Hispanics' views on racial matters resemble African Americans' (Bobo \& Hutchings, 1996).

7. Davis (1997) finds that African Americans are more deferential toward White than Black survey interviewers. However, this dynamic seems more likely in the private sphere than in a public, political forum; more likely when Whites are present in their capacity as authority figures (i.e., interviewers) than when Whites are present as fellow citizens; and more likely when Blacks are alone rather than with other Blacks.

8. African Americans and Hispanics together make up less than $10 \%$ of the student body in the schools of these towns, and in none of them do African Americans constitute more than $3 \%$ of enrollment.

9. We focus on the meeting in Leonia because it was the largest. The Englewood meeting was the only one attended by large numbers of minority group members and in which regionalization was supported.

10. Because the audio was of uneven quality, approximately $10 \%$ of the sentences were check-transcribed; $9.3 \%$ of the sentences were transcribed with substantial discrepancies or were largely incomplete (in which case they were not included). The coding unit was the sentence (longer sentences were divided into parts). Each sentence was coded into only one category. The 
categories were initially developed from our reading of studies of school desegregation and of the newspaper coverage of this controversy. These preliminary categories were refined after we read through a sample of the transcript. In the process of refining the categories, we added those of "outsiders" and "multicultural." We went through several iterations to more cleanly divide our definitions of "neighborhood schools" and "outsiders." The former included sentences that focus on the harm to "community based schools" or the need to protect them. The latter focused on infringements on "local control" or "established municipal boundaries," the right of parents to determine where children attend school, or coercion by "the state" or "state contractors." A sentence such as "Governor Whitman, the Tenafly Board calls on you to put yourself in opposition to the dismemberment of our community schools" would be classified in the "neighborhood schools" category because it focuses on the damage to community schools. A sentence such as "Governor Whitman, we will not allow state contractors armed with quotas, computers, and buses to decide where our children attend school" would be classified in the "outsiders" category because it focuses on the abrogation of self-rule by outside forces.

11. The audience was easily separable on sight into Englewood and non-Englewood sections by the buttons worn by non-Englewood residents.

12. As residents filed into Leonia High School for the meeting, members of the Leonia School Board hung a banner reading "Leonia Insists on Neighborhood Schools," which was identical to a banner hanging across Leonia's main thoroughfare. Yellow buttons were handed out bearing the same slogan. Leonia Board of Education members began the meeting by announcing a parade to be held to protest the "forced" regionalization plan.

13. Some might say that the best arena for the study of deliberation is the jury. However, juries also suffer from bias and inequality and thus are likely to generate less-than-ideal deliberation (Sanders, 1997). Moreover, they are inadequate for our aim, charged as they are with determining an individual's guilt rather than discussing government policy.

14. Liberal theorists see nothing wrong with conflictual deliberation, but they endorse it only when it is reasoned, factual, and open-minded and it leads to less alienation from democracy.

15. Some deliberative theorists acknowledge the large distance between prerequisites for deliberation and the conditions that exist in reality (Cohen, 1989; Fraser, 1993), but it is unclear how remedies such as publicly financed strong parties can alleviate the problems we found.

\section{References}

Barber, B. (1984). Strong democracy: Participatory politics for a new age. Berkeley: University of California Press.

Benhabib, S. (1996). Toward a deliberative model of democratic legitimacy. In S. Benhabib (Ed.), Democracy and difference: Contesting the boundaries of the political (pp. 67-94). Princeton, NJ: Princeton University Press.

Bickford, S. (1996). Beyond friendship: Aristotle on conflict, deliberation, and attention. Journal of Politics, 58, 398-421.

Board of Education of the Borough of Englewood Cliffs, Bergen County v. Board of Education of City of Englewood, 257 N.J. Super. 413 (1992).

Board of Education of the Borough of Englewood Cliffs, Bergen County v. Board of Education of City of Englewood,132 N.J. Super. 327 (1993).

Bobo, L., \& Hutchings, V. (1996). Perceptions of racial group competition: Extending Blumer's theory of group position to a multiracial social context. American Sociological Review, 61, 951-972.

Bohman, J. (1996). Public deliberation. Cambridge, MA: MIT Press.

Brewer, M., \& Miller, N. (1988). Contact and cooperation: When do they work? In P. Katz \& D. Taylor (Eds.), Eliminating racism: Profiles in controversy (pp. 315-328). New York: Plenum.

Carsey, T. (1995). The contextual effects of race on White voter behavior: The 1989 New York City mayoral election. Journal of Politics, 57, 221-228. 
Chambers, S. (1996). Reasonable democracy. Ithaca, NY: Cornell University Press.

Cohen, J. (1989). Deliberation and democratic legitimacy. In A. Hamlin \& P. Pettit (Eds.), The good polity: Normative analysis of the state (pp. 17-34). Cambridge, England: Basil Blackwell.

Davis, D. (1997). Interviewer effects. Public Opinion Quarterly, 61, 183-207.

Dawson, M. (1994). Behind the mule. Princeton, NJ: Princeton University Press.

Delli Carpini, M., \& Williams, B. (1994). The method is the message: Focus groups as a method of social, psychological, and political inquiry. In M. Delli Carpini, L. Huddy, \& R. Shapiro (Eds.), Research in micropolitics (Vol. 4, pp. 57-86). Greenwich, CT: Norwich.

Elster, J. (1998). Deliberation and constitution making. In J. Elster (Ed.), Deliberative democracy (pp. 97-122). Cambridge, England: Cambridge University Press.

Entman, R. (1992). Blacks in the news: Television, modern racism and cultural change. Journalism Quarterly, 69, 341-361.

Entman, R., \& Rojecki, A. (1996, November). Advertising boundaries: Race and intimacy in television commercials. Paper presented at the meeting of the International Communication Association, Chicago.

Fishkin, J. (1991). Democracy and deliberation: New directions for democratic reform. New Haven, CT: Yale University Press.

Fraser, N. (1993). Rethinking the public sphere. In C. Calhoun (Ed.), Habermas and the public sphere (pp. 109-142). Cambridge, MA: MIT Press.

Gastil, J., \& Dillard, J. (1999). Increasing political sophistication through public deliberation. Political Communication, 16, 3-23.

Gilens, M. (1999). Why Americans hate welfare. Chicago: University of Chicago Press.

Green, D., Strolovitch, D., \& Wong, J. (1998). Defended neighborhoods, integration, and hate crime. American Journal of Sociology, 104, 372-403.

Gutmann, A., \& Thompson, D. (1996). Democracy and disagreement. Cambridge, MA: Harvard University Press.

Habermas, J. (1989). The structural transformation of the public sphere (T. Burger, Trans.). Cambridge, MA: MIT Press.

Himelstein, J. (1983). Rhetorical continuities in the politics of race: The closed society revisited. Southern Speech Communication Journal, 48, 153-166.

Hochschild, J. (1984). The new American dilemma: Liberal democracy and school desegregation. New Haven, CT: Yale University Press.

Hurwitz, J., \& Peffley, M. (1997). Public perceptions of race and crime: The role of racial stereotypes. American Journal of Political Science, 41, 375-401.

Jamieson, K. H. (1992). Dirty politics: Deception, distraction, and democracy. New York: Oxford University Press.

Kinder, D., \& Mendelberg, T. (1995). Cracks in American apartheid: The political impact of prejudice among desegregated Whites. Journal of Politics, 57, 402-424.

Kinder, D., \& Sanders, L. (1996). Divided by color. Chicago: University of Chicago Press.

Kuklinski, J., \& Hurley, N. (1994). On hearing and interpreting political messages: A cautionary tale of citizen cue-taking. Journal of Politics, 56, 729-751.

Mansbridge, J. (1983). Beyond adversary democracy. Chicago: University of Chicago Press.

Mansbridge, J. (1990). Feminism and democracy. American Prospect, 1, 126-139.

Mansbridge, J. (1996). Using power/fighting power: The polity. In S. Benhabib (Ed.), Democracy and difference: Contesting the boundaries of the political (pp. 46-66). Princeton, NJ: Princeton University Press.

Mendelberg, T. (1999). Mobilizing race in the age of equality. Unpublished manuscript, Princeton University.

Merelman, R., Streich, G., \& Martin, P. (1998). Unity and diversity in American political culture: An exploratory study of the National Conversation on American Pluralism and Identity. Political Psychology, 19, 781-808.

Mill, J. S. (1975). On liberty. New York: Norton. (Original work published 1859)

Mutz, D. (1999). Communication across lines of political difference. Unpublished manuscript, University of Wisconsin-Madison. 
New Jersey State Data Center. (1994). Population by race and Hispanic origin. Trenton: NJ: Author.

O'Reilly, K. (1995). Nixon's piano: Presidents and racial politics from Washington to Clinton. New York: Free Press.

Sanders, L. (1997). Against deliberation. Political Theory, 25, 347-376.

Schneider, M., Marschall, M., Teske, P., \& Roch, C. (1998). School choice and culture wars in the classroom: What parents seek from education. Social Science Quarterly, 79, 489-501.

Schuman, H., Steeh, C., Bobo, L., \& Krysan, M. (1997). Racial attitudes in America. Cambridge, MA: Harvard University Press.

Sears, D., \& Citrin, J. (1985). Tax revolt: Something for nothing in California. Cambridge, MA: Harvard University Press.

Sigelman, L., \& Welch, S. (1991). Black Americans' views of racial inequality: The dream deferred. New York: Cambridge University Press.

Stewart, B. (1995, June 11). School colors. The New York Times, 13NJ, p. 1.

Sunstein, C. (1993). Democracy and the problem of free speech. New York: Free Press.

Theiss-Morse, E., Marcus, G., \& Sullivan, J. (1993). Passion and reason in political life: The organization of affect and cognition and political tolerance. In R. Hanson \& G. Marcus (Eds.), Reconsidering the democratic public (pp. 249-272). University Park: Pennsylvania State University Press.

Voss, D. S. (1996). Beyond racial threat: Failure of an old hypothesis in the new South. Journal of Politics, 58, 1156-1170.

Walzer, M. (1997). Deliberation, and what else? Unpublished manuscript.

Warren, M. (1992). Democratic theory and self-transformation. American Political Science Review, 86, 8-23.

Warren, M. (1996). Deliberative democracy and authority. American Political Science Review, 90, $46-60$.

Young, I. (1996). Communication and the other: Beyond deliberative democracy. In S. Benhabib (Ed.), Democracy and difference: Contesting the boundaries of the political (pp. 120-136). Princeton, NJ: Princeton University Press.

Zaller, J. (1992). The nature and origins of mass opinion. Cambridge, England: Cambridge University Press. 